\author{
JOLANTA BLICHARZ \\ ORCID: 0000-0002-4581-8629 \\ Uniwersytet Wrocławski \\ Instytut Nauk Administracyjnych \\ Zakład Prawa Administracyjnego
}

\title{
UMOWA O PRZEKAZANIE PROWADZENIA SZKOEY PODMIOTOWI POZARZĄDOWEMU. KILKA UWAG O STANIE OBECNYM WEDŁUG PRAWA OŚWIATOWEGO
}

\begin{abstract}
Abstrakt: Ustawa Prawo oświatowe operując pojęciem umowy, podając jej niezbędne elementy, nie aspiruje do tego, by traktować ją jako typową umowę nazwaną, czyli taką, której treść jest stypizowana normatywnie. W założeniach ustawy umowa ta ma być rozumiana raczej jako sposób realizacji zadania publicznego, w ramach umowy zawierającej niezbędne elementy charakterystyczne dla danego typu umowy cywilnoprawnej.
\end{abstract}

Słowa kluczowe: szkoła publiczna, zadania publiczne, prywatyzacja zadań publicznych, umowa prawa publicznego (publicznoprawna), umowa prawa prywatnego (prywatnoprawna).

Na marginesie tych rozważań można zauważyć, iż zgodnie z treścią art. 3 ustawy z dnia 14 grudnia 2016 roku Prawo oświatowe ${ }^{1}$,System oświaty wspierają organizacje pozarządowe, $w$ tym organizacje harcerskie, a także osoby prawne prowadzące statutową działalność w zakresie oświaty i wychowania” (ust. 1). „System oświaty w zakresie kształcenia zawodowego wspierają także pracodawcy, organizacje pracodawców, samorządy gospodarcze lub inne organizacje gospodarcze, stowarzyszenia lub samorządy zawodowe, sektorowe rady do spraw kompetencji oraz Rada Programowa do spraw kompetencji, o których mowa w ustawie z dnia 9 listopada $2000 \mathrm{r}$. o utworzeniu Polskiej Agencji Rozwoju Przedsiębiorczości” (ust. 1a). „System oświaty mogą wspierać także jednostki organizacyjne Państwowej Straży Pożarnej oraz jednostki innych właściwych służb w działaniach służących podnoszeniu bezpieczeństwa dzieci i młodzieży, w tym w zakresie ochrony przeciwpożarowej” (ust. 3).

${ }^{1}$ Ustawa z dnia 14 grudnia 2016 roku Prawo oświatowe, Dz.U. z 2019 r. poz. 1148, 1078, 1287, 1680, 1681, 1818, 2197 i 2248; oraz z 2020 r. poz. 374. 
Z góry można założyć, że nie mamy do czynienia z identycznymi pod względem prawnym instytucjami wspierającymi system oświaty, choć niewątpliwie mogącymi służyć wspólnemu celowi. Wyróżnione podmioty stanowią formy organizacyjno-prawne szeroko pojętego społeczeństwa obywatelskiego - otwierają przestrzeń współdziałania różnych form aktywności obywateli z organami administracji publicznej w sferze realizacji zadań oświatowych ${ }^{2}$.

Jeżeli chodzi o zakres wspierania systemu oświaty przez wyróżnione podmioty, to problematyka ta ma różne wymiary, a realizacja przyjętych założeń przebiega na wielu płaszczyznach oraz $\mathrm{w}$ różnym zakresie przedmiotowym. W różnym stopniu znajdują one wyraz w aktach prawnych. Pozwala to przyjąć, że upo i jej rozwiązania otwierają dość rozległe pole inicjatyw współdziałania organów administracji publicznej z danymi podmiotami w sferze realizacji określonych zadań w obszarze oświaty (na przykład upowszechnianie wśród dzieci i młodzieży wiedzy i umiejętności niezbędnych do aktywnego uczestnictwa w kulturze i sztuce narodowej i światowej, czy też możliwość prowadzenia szkół i placówek publicznych lub niepublicznych) ${ }^{3}$.

$\mathrm{Na}$ tym tle powstaje jednak szereg istotnych problemów prawnych. Można na przykład postawić pytanie, co należy rozumieć pod pojęciem wspierania systemu oświaty ${ }^{4}$ albo czy prawnie możliwe formy wspierania rozwoju szkoły zapewniają właściwe jej funkcjonowanie. Jest to odrębne, obszerne zagadnienie wykraczające poza ramy tego artykułu. Na bazie obowiązującej ustawy warto również otworzyć dyskusję nad problemem - czy i w jaki sposób uregulowania zawarte w upo, dotyczące umowy o przekazanie prowadzenia szkoły podmiotowi pozarządowemu, zespolone zostały z działalnością pożytku publicznego, prowadzoną przez organizacje pozarządowe w sferze realizacji zadań publicznych obejmujących zadania między innymi z zakresu edukacji, oświaty i wychowania ${ }^{5}$. Zagadnieniu temu nie poświęca się chyba dostatecznej uwagi, a ma ono - jak się wydaje — istotne znaczenie dla określenia charakteru prawnego umowy o przekazanie szkoły do prowadzenia wyróżnionym podmiotom. Z uwagi na zawężone pole rozważań opracowanie nie obejmuje analizy skutków przekazania prowadzenia szkoły publicznej, dotyczących spraw pracowniczych, czy warunków korzystania z mienia przejętej szkoły. Analiza tych zagadnień przekraczałaby rozmiary niniejszego opracowania.

2 Szerzej: J. Blicharz, Wplyw spoleczeństwa obywatelskiego na efektywność zarządzania wadministracji publicznej (wybrane problemy), [w:] Między tradycja a przyszłościa w nauce prawa administracyjnego, red. J. Supernat, Wrocław 2009, s. 37.

3 Zob. art 1 i art. 8 upo.

${ }^{4}$ W literaturze zwraca się uwagę, iż pojęcie wspierania odnosi się do finansowej i organizacyjnej pomocy podmiotom publicznoprawnym (to znaczy państwu i organom samorządu terytorialnego) w zapewnieniu sprawnego funkcjonowania (poszczególnych ogniw) systemu edukacji — zob. R. Raszewska-Skałecka, Trzeci sektor w systemie oświaty - wybrane formy wspierajace oświatę, [w:] Trzeci sektor i ekonomia społeczna. Uwarunkowania prawne. Kierunki rozwoju, red. J. Blicharz, L. Zacharko, Wrocław 2017, s. 124.

5 Zob. art. 4 ust. 1 pkt 14 ustawy z dnia 24 kwietnia 2003 roku o działalności pożytku publicznego i o wolontariacie, tekst jedn. Dz.U. z 2020 r. poz. 284. 
Obecnie nie toczy się już fundamentalnych sporów teoretycznych dotyczących istoty organizacji pozarządowych, co miało miejsce jeszcze przed 2003 rokiem ${ }^{6}$. Okazuje się, że instytucje te są tak głęboko zakorzenione w świadomości prawników, iż nie ma potrzeby ponownego teoretycznego ich konstruowania. Zgodnie $\mathrm{z}$ definicją zawartą $\mathrm{w}$ udppw ${ }^{7}$ do podstawowych elementów przesądzających o charakterze tych podmiotów należy zaliczyć: formę wyodrębnienia organizacyjnego, powodującą ich lokalizację poza jednostkami należącymi do sektora finansów publicznych, niezarobkowy charakter, a także cel działalności. Oparcie prawnej definicji organizacji pozarządowych na koncepcji odrębności tych podmiotów od jednostek sektora finansów publicznych ma znaczenie przede wszystkim z punktu widzenia braku powiązań organizacyjnych i finansowych wyróżnionych organizacji z jednostkami tego sektora. $Z$ zakresu pojęciowego podmiotów pozarządowych należy wyłączyć również przedsiębiorstwa, instytuty badawcze, banki i spółki prawa handlowego będące państwowymi lub samorządowymi osobami prawnymi. Należy także podkreślić, że fundacje i stowarzyszenia stanowią podstawowe komponenty sektora organizacji pozarządowych ${ }^{8}$. Dla naszych celów wydaje się więc uzasadnione wstępne założenie, że podmioty tak zwanego trzeciego sektora rozpatrywać należy przede wszystkim jako podmioty prawa prywatnego, które w odróżnieniu od sektora biznesu działają w interesie publicznym (ogólnym), a nie prywatnym. Trzeba też wskazać, że konstrukcja organizacji trzeciego sektora jest związana z koncepcją działalności pożytku publicznego, z którą wiąże się w szczególny sposób czynnik społecznej użyteczności w sferze realizacji zadań publicznych przy współpracy z organami administracji publicznej ${ }^{9}$.

Analizując charakter prawny umowy o przekazanie szkoły do prowadzenia podmiotowi niepublicznemu (pozarządowemu), przede wszystkim odnieść się

${ }^{6}$ Prawna definicja organizacji pozarządowej zaistniała wraz z wejściem w życie ustawy o działalności pożytku publicznego i o wolontariacie (dalej: udppw).

7 W trybie art. 3 ust. 2 udppw „organizacjami pozarządowymi są: 1) niebędące jednostkami sektora finansów publicznych w rozumieniu ustawy z dnia 27 sierpnia 2009 roku o finansach publicznych lub przedsiębiorstwami, instytutami badawczymi, bankami i spółkami prawa handlowego będącymi państwowymi lub samorządowymi osobami prawnymi; 2) niedziałające w celu osiągnięcia zysku - osoby prawne lub jednostki organizacyjne nieposiadające osobowości prawnej, którym odrębna ustawa przyznaje zdolność prawną, w tym fundacje i stowarzyszenia”.

${ }^{8}$ Por. J. Blicharz, Ustawa o dziatalności pożytku publicznego $i$ o wolontariacie. Ustawa o spóldzielniach socjalnych. Komentarz, Warszawa 2012, s. 49 n.

9 Szerzej: eadem, Problem implementacji dyrektywy ustugowej UE $w$ odniesieniu do organizacji trzeciego sektora w Polsce, „Przegląd Prawa i Administracji” 79, 2009, s. 27 n. 
należy do treści art. 9 ust. 1 upo, zgodnie z którym jednostka samorządu terytorialnego, będąca organem prowadzącym szkołę liczącą nie więcej niż siedemdziesięciu uczniów, na podstawie uchwały organu stanowiącego tej jednostki oraz po uzyskaniu pozytywnej opinii organu sprawującego nadzór pedagogiczny, może przekazać, w drodze umowy, osobie prawnej niebędącej jednostką samorządu terytorialnego lub osobie fizycznej prowadzenie takiej szkoły ${ }^{10}$. Umowa o przekazanie szkoły musi określać w szczególności: wskazanie, czy szkole ustala się obwód, a jeżeli szkole nie ustala się obwodu — warunki przyjmowania uczniów do szkoły; tryb przejęcia szkoły lub placówki przez jednostkę samorządu terytorialnego w przypadku niezdolności zleceniobiorcy do jej dalszego prowadzenia; warunki korzystania z mienia przejętej szkoły; tryb kontroli przestrzegania warunków umowy; warunki i tryb rozwiązania umowy za wypowiedzeniem.

Sama ustawa nie wyczerpuje wszystkich nasuwających się tu zagadnień związanych z wymaganiami, jakie powinien spełniać podmiot pozarządowy przejmujący prowadzenie szkoły samorządowej (na przykład oceny jego możliwości w zakresie realizacji zadania publicznego czy udziału środków finansowych własnych lub środków pochodzących z innych źródeł na jego realizację). Poruszone wyżej kwestie mają także wpływ na charakter prawny umowy o przekazanie prowadzenia szkoły podmiotowi pozarządowemu.

Zwrócić należy jeszcze uwagę, że z prawnego punktu widzenia proces przekazywania prowadzenia szkoły publicznej przez jednostkę samorządu terytorialnego (dalej: jst) podmiotowi zewnętrznemu (na przykład organizacji pozarządowej) obejmuje w pierwszym rzędzie podjęcie przez organ stanowiący tej jednostki uchwały wyrażającej wolę tego organu co do przekazania prowadzenia szkoły, której ważność (w sensie możliwości wywołania zamierzonego skutku prawnego) jest uzależniona od wydania pozytywnej opinii przez organ sprawujący nadzór pedagogiczny, co wypełnia dyspozycję art. 89 ust. 1 ustawy o samorządzie gminnym $^{11}$, a następnie zawarcie przez jst umowy $\mathrm{z}$ danym podmiotem, który zamierza przejąć prowadzenie szkoły.

10 Trudności z klasyfikacją wyróżnionych podmiotów mogą wynikać z faktu, że struktura podmiotowa jest rozbudowana i obejmuje różne podmioty o odmiennym charakterze — zob. J. Pierzchała, Prawo oświaty prywatnej, Warszawa 2016, s. 87. Warto zaznaczyć, iż przekazywanie szkoły do prowadzenia podmiotom zewnętrznym nie jest rozwiązaniem obligatoryjnym, jednak ze względów demograficznych i z powodu kryzysu finansów publicznych (również samorządowych) jest to rozwiązanie szczególnie zyskujące w ostatnim czasie na popularności. W szczególności pozwala uniknąć likwidacji placówki — zob. R. Raszewska-Skałecka, Współczesne wyzwania i dylematy zarządzania oświata samorzadowa. Spoleczne inicjatywy edukacyjne, [w:] Przegląd dyscyplin badawczych pokrewnych nauce prawa i postepowania administracyjnego, red. S. Wrzosek et al., Lublin 2010, s. 632.

${ }^{11}$ Ustawa z dnia 8 marca 1990 roku o samorządzie gminnym (tekst jedn. z 2020 r. poz. 713) — dalej: usg), art. 89: „1. Jeżeli prawo uzależnia ważność rozstrzygnięcia organu gminy od jego zatwierdzenia, uzgodnienia lub zaopiniowania przez inny organ, zajęcie stanowiska przez ten organ powinno nastąpić nie później niż w ciągu 14 dni od dnia doręczenia tego rozstrzygnięcia lub jego 
Warto też zaznaczyć, iż zgodnie ze stanowiskiem Naczelnego Sądu Administracyjnego (dalej: NSA) opinia organu sprawującego nadzór pedagogiczny jest środkiem nadzoru określonym art. 89 ust. 1 usg, a tym samym aktem nadzoru, o którym mowa w art. $3 \S 2$ pkt 7 ustawy z dnia 30 sierpnia 2002 roku Prawo o postępowaniu przed sądami administracyjnymi ${ }^{12}$. W rezultacie podlega zaskarżeniu do sądu administracyjnego w terminie 30 dni od jej doręczenia. Podstawą zaskarżenia może być niezgodność opinii z prawem.

Należy też podkreślić, że upo nie zawiera w swej treści przepisu, który odsyłałby bezpośrednio do postanowień udppw (na przykład konkurencyjnego trybu wyłonienia podmiotu, który uzyskuje zlecenie prowadzenia szkoły). Choć przedmiotem obu regulacji (upo i udppw) jest powierzanie podmiotom pozarządowym do realizacji w drodze zawieranych umów zadań, jakie w świetle obowiązujących ustaw przypisane są podmiotom publicznym, to jednak zakres stosowania udppw jest niewątpliwie szerszy niż regulacji dotyczącej upo, albowiem w art. 4 ust. 1 udppw w trzydziestu dziewięciu punktach zostało scharakteryzowane pojęcie sfery zadań publicznych, a zadania z zakresu oświaty są tylko jednym ich rodzajem. Ponadto w odniesieniu do udppw — wzory ofert, umów i sprawozdań, czyli podstawowych dokumentów systemu zlecania zadań publicznych, określają rozporządzenia wykonawcze ${ }^{13}$.

projektu, z zastrzeżeniem ust. 1a. 1a. Termin, o którym mowa w ust. 1, wynosi 30 dni, jeżeli zatwierdzenie, uzgodnienie lub zaopiniowanie wymagane jest od organu stanowiącego jednostki samorządu terytorialnego. 2. Jeżeli organ, o którym mowa w ust. 1 lub 1a, nie zajmie stanowiska w sprawie, rozstrzygnięcie uważa się za przyjęte w brzmieniu przedłożonym przez gminę, z upływem terminu określonego w ust. 1 lub 1a".

12 Tekst jedn. Dz.U. z 2019 r. poz. 2325. Zob. też wyrok NSA z dnia 4 kwietnia 2013 roku, I OSK 93/13, CBOSA, zgodnie z którym przez pojęcie „akt nadzoru” należy rozumieć wszelkiego rodzaju akty organów państwa (nie tylko organów nadzoru w rozumieniu art. 171 Konstytucji Rzeczypospolitej Polskiej), którym prawo przyznało kompetencję do stosowania wobec organów samorządu terytorialnego jakiegokolwiek środka nadzoru. W tej kwestii por. także: Z. Kmieciak, M. Stahl, Akty nadzoru nad działalnością samorządu terytorialnego (w świetle ustaleń orzecznictwa NSA i poglądów doktryny), „Samorząd Terytorialny” 2001, nr 1-2, s. 92 n. W przedmiocie charakteru prawnego „opinii kuratora” wypowiadał się też Trybunał Konstytucyjny w wyroku z dnia 8 maja 2002 roku, sygn. akt K 29/00: „w tym przypadku mamy do czynienia z dopuszczalnym »współdziałaniem fachowym « w rozumieniu art. 89 i art. 98 ustawy o samorządzie gminnym, mieszczącym się w granicach ustanowionej konstytucyjnie zasady współdziałania władz (preambuła do Konstytucji). [...] Analiza zadań i kompetencji kuratora jednoznacznie wskazuje, że pełni on w polskim systemie oświaty szczególną rolę organu administracji rządowej, odpowiedzialnego za realizację polityki oświatowej państwa na terenie właściwego województwa, a jednocześnie obarczonego obowiązkiem takiego współtworzenia i realizowania regionalnej i lokalnej polityki oświatowej (art. 31 pkt 6), aby ta ostatnia pozostawała w zgodzie z polityką oświatową państwa. Taka pozycja kuratora oświaty jest mocno ugruntowana w tradycji Państwa Polskiego, co musi być również brane pod uwagę przy określaniu jego relacji z jednostkami samorządu terytorialnego, odpowiedzialnymi za prowadzenie szkół. Opinia kuratora ma charakter rozstrzygnięcia celowego" — Dz.U. z 2002 r. Nr 66, poz. 612.

13 Zob. rozporządzenie Przewodniczącego Komitetu do spraw Pożytku Publicznego z dnia 24 października 2018 roku (Dz.U. z 2018 r. poz. 2057); rozporządzenie Przewodniczącego Komitetu 
Co prawda, przepisy udppw określają podstawowe zasady organizowania i rozstrzygania konkursów, w tym obligatoryjną zawartość ogłoszenia o konkursie, niemniej jednak w sytuacji, gdy wspieranie oraz powierzanie zadań publicznych jest finansowane z niepodlegających zwrotowi środków pochodzących ze źródeł zagranicznych, wybór może nastąpić na zasadach i w trybie ustawy o partnerstwie publiczno-prywatnym albo na podstawie umów międzynarodowych (art. 11 ust. 5). W szczególnych zaś sytuacjach ustawodawca dopuszcza także zlecenie zadań publicznych z pominięciem otwartego konkursu ofert w art. 11a (w razie wystąpienia klęski żywiołowej, katastrofy naturalnej lub awarii technicznej), art. 11b (jeżeli jest to niezbędne ze względu na ochronę życia lub zdrowia ludzkiego albo ze względu na ważny interes społeczny lub ważny interes publiczny), art. 11c (w przypadkach dotyczących zadań z zakresu ochrony ludności i ratownictwa), art. 19a (tak zwana uproszczona oferta na realizację zadania publicznego).

Choć w odniesieniu do umowy o powierzenie zadania publicznego zawieranej na podstawie udppw dominują poglądy o jej cywilnoprawnym charakterze ${ }^{14}$, to w przypadku umowy o przekazanie prowadzenia szkoły podmiotowi zewnętrznemu (osobie fizycznej lub osobie prawnej) spotkać można się z koncepcjami uznawania jej zarówno za umowę cywilnoprawną ${ }^{15}$, jak i za umowę publicznoprawną ${ }^{16}$.

Oczywiście przypisanie danej umowie charakteru publiczno- czy też prywatnoprawnego wielokrotnie może się okazać zadaniem niełatwym, zwłaszcza że ustawodawca zazwyczaj nie wypowiada się jednoznacznie w kwestii jej charakteru prawnego. Ponadto w literaturze używa się niekiedy określenia, iż na przykład w danej umowie występują , „elementy prywatnoprawne”, jak również „elementy publicznoprawne", z tym że niekiedy jedne z nich mogą przeważać ${ }^{17}$.

Odnosząc się do charakteru prawnego umowy o przekazanie szkoły do prowadzenia podmiotowi niepublicznemu (pozarządowemu), należy w pierwszej kolejności podnieść, iż umowy stanowią ważny instrument realizacji zadań przede

do spraw Pożytku Publicznego z dnia 24 października 2018 roku w sprawie uproszczonego wzoru oferty i uproszczonego wzoru sprawozdania z realizacji zadania publicznego (Dz.U. z 2018 r. poz. 2055).

14 Por. A. Trela, Powierzanie zadań z zakresu gospodarki komunalnej a swoboda zawierania umów, „Ruch Prawniczy, Ekonomiczny i Socjologiczny” 77, 2015, z. 3, s. 254. Zob. też postanowienie NSA z 10 sierpnia 2018 roku, I GSK 2684/18, CBOSA.

15 W kwestii charakteru tych umów jako cywilnoprawnych zob. D. Sześciło, Prywatyzacja prowadzenia szkót samorządowych do poprawki, https://www.prawo.pl/samorzad/prywatyzacja-prowadzenia-szkol-samorzadowych-do-poprawki,98190.html (dostęp: 31.01.2020).

${ }^{16} \mathrm{~W}$ doktrynie zwraca się uwagę, że trudno uznać ją za typową czynność cywilnoprawną ze względu na powierzenie na jej podstawie realizacji zadań publicznych, a także zachowanie ścisłej kontroli administracji publicznej nad jej realizacją — zob. M. Pilich, Ustawa o systemie oświaty. Komentarz, Warszawa 2012, s. 71-72.

17 Zob. T. Rabska, Kontrakt wojewódzki - forma działania administracji publicznej w strukturach zdecentralizowanych, [w:] Instytucje współczesnego prawa administracyjnego. Księga pamiątkowa prof. zw. dra hab. J. Filipka, Kraków 2001, s. 611. 
wszystkim w sferze administracji świadczącej ${ }^{18}$. Towarzyszy temu zjawisko prywatyzacji zadań publicznych. Umowne formy działania administracji obejmują zarówno umowy cywilnoprawne, jak i umowy prawa publicznego (przede wszystkim umowy administracyjne $)^{19}$. Jednym z kryteriów wyodrębnienia umów publicznoprawnych (umów administracyjnych) jest szczególna pozycja podmiotu publicznego. Jak słusznie podkreśla się w literaturze, niezależnie od charakteru prawnego umowy nie są zawierane w ramach swobody kontraktowej ${ }^{20}$. Przede wszystkim przepisy prawa administracyjnego wyraźnie określają zasady i warunki ich zawierania. W konsekwencji bez wyraźnego upoważnienia ustawowego administracja nie może realizować zadań publicznych w formie kontraktowej ${ }^{21}$.

$\mathrm{Z}$ teoretycznego punktu widzenia poglądy na temat charakteru prawnego umowy o przekazanie szkoły osobie fizycznej lub prawnej są zróżnicowane. Niektórzy autorzy (Mateusz Pilich) opowiadają się za publicznoprawnym charakterem tej umowy, o czym świadczy między innymi „szczególny tryb zawierania umowy i powierzenie $\mathrm{w}$ ten sposób pewnej funkcji przypisywanej tradycyjnie aparatowi administracji publicznej, lecz także zachowanie przez jst, która przekazuje do prowadzenia szkołę, stałej kontroli nad realizacją przez drugą stronę umowy jej celu — dalszego utrzymywania działalności tejże szkoły"22.

Odrębne stanowisko zajmuje Dawid Sześciło. Jego zdaniem analizowaną umowę należy uznać za czynność cywilnoprawną, która dochodzi do skutku w warunkach istotnego ograniczenia swobody umów i której przedmiotem jest wykonywanie zadań publicznych. Jednocześnie zwraca on uwagę, iż umowa ta nie różni się zasadniczo od innych umów zawieranych przez podmioty administracji publicznej w ramach wykonywania zadań publicznych, na przykład umowy o powierzenie lub wspieranie realizacji zadania publicznego uregulowanej w udppw ${ }^{23}$. Prezentowane

18 Szerzej: R. Raszewska-Skałecka, Szkoła publiczna jako zdecentralizowany podmiot administracji publicznej. Studium administracyjnoprawne, Wrocław 2019, s. 145 n. W kwestii prywatyzacji zadań publicznych w dziedzinie edukacji — zob. eadem, Udziat organizacji pozarzadowych w rozwiązywaniu lokalnych konfliktów edukacyjnych na tle rozwiąań prawnych, [w:] Płaszczyzny konfliktów $w$ administracji publicznej, red. M. Tabernacka, R. Raszewska-Skałecka, Warszawa 2010, s. 466-498. Także w tej sprawie: L. Zacharko, A. Zacharko, Umowa publicznoprawna jako forma realizacji zadań publicznych w Unii Europejskiej, [w:] Wzajemne oddziaływanie gałęzi prawa publicznego i prywatnego, red. P. Bieś-Srokosz, J. Srokosz, E. Żelasko-Makowska, Częstochowa 2017, s. 71-81.

19 Szerzej: A. Miruć, O roli i specyfice umów w działaniach administracji pomocy społecznej, [w:] Cywilizacja administracji publicznej. Ksiega jubileuszowa z okazji 80-lecia urodzin prof. nadzw. UWr dra hab. Jana Jeżewskiego, Wrocław 2019, s. 326.

20 T. Kocowski, Umowa w działaniach administracji publicznej, [w:] Stan i kierunki rozwoju nauk administracyjnych, red. A. Błaś, J. Boć, Wrocław 2014, s. 302-303.

21 Ibidem, s. 302.

${ }^{22}$ M. Pilich, op. cit., s. 73. W doktrynie można też spotkać się ze stanowiskiem głoszącym cywilnoprawną naturę czynności prawnej „przekazania”, natomiast publicznoprawny charakter samej umowy — zob. D. Kurzyna-Chmiel, Oświata jako zadanie publiczne, Warszawa 2013, s. 298.

23 Zob. D. Sześciło, op. cit. 
jest też stanowisko, że umowy wykorzystywane do powierzania zadań publicznych to przykład umów pozakodeksowych, a ich treści są kształtowane przepisami prawa administracyjnego, lecz nie tracą one cywilnego charakteru ${ }^{24}$. W konsekwencji już teraz można stwierdzić, że w literaturze możemy spotkać wypowiedzi o pewnej stopniowalności publicznego lub prywatnego charakteru danej umowy.

Problem jest wielowątkowy i wyjątkowo trudny, także w sensie prawnym. Wobec ustanowionej w upo możliwości przekazania szkoły publicznej w drodze umowy warto też odnieść się do tego, jaka jest pozycja podmiotu niepublicznego (organizacji pozarządowej). W tym względzie odpowiedź wydaje się nasuwać już sama. Ustawodawca wyraźnie wskazuje, że jednostka samorządu terytorialnego ma wyłączne prawo inicjowania działań mających na celu zawarcie umowy o przekazanie prowadzenia szkoły. Podmiotowi niepublicznemu pozostawiono jedynie możliwość przystąpienia do zawarcia takiej umowy.

Kolejny punkt odniesienia może stanowić to, że szkoła przejęta do prowadzenia przez organizację pozarządową nie traci statusu szkoły publicznej. Stosuje się do niej przepisy dotyczące szkół i placówek publicznych prowadzonych przez osoby prawne niebędące jednostkami samorządu terytorialnego lub osoby fizyczne (art. 9 ust. 4 upo). Ponadto, co istotne, zleceniobiorca nie może zlikwidować przejętej szkoły. W sytuacji utraty zdolności do dalszego wykonywania tego zadania powinien złożyć wniosek do jst, która przekazała szkołę, o przejęcie prowadzenia szkoły. W tym przypadku umowa ulega rozwiązaniu z dniem przejęcia szkoły przez jednostkę samorządu terytorialnego (art. 9 ust. 5 i ust. 6 upo).

Takie rozwiązanie nie powinno dziwić z uwagi na to, że zadaniem jst jest jak najlepsze zabezpieczenie interesu publicznego. W tym kierunku również zdaje się iść ustawodawca. Generalnie można powiedzieć, że z punktu widzenia zawartych w upo przepisów pozycja podmiotu niepublicznego względem drugiej strony umowy — jednostki samorządu terytorialnego — jest słabsza.

W orzecznictwie sądów administracyjnych przyjmowane jest stanowisko, zgodnie z którym umowa przekazania przez jednostkę samorządu terytorialnego prowadzenia szkoły osobie fizycznej lub prawnej ma charakter cywilnoprawny ${ }^{25}$. Oczywiste jest, że podstawą działania jst nie może być sama zasada swobody umów ${ }^{26} . \mathrm{W}$ tym wypadku tak zwana zasada swobody umów, pojmowana jako

${ }^{24}$ R. Stasikowski, Funkcja regulacyjna administracji publicznej. Studium z zakresu nauki prawa administracyjnego oraz nauki administracji, Bydgoszcz-Katowice 2008, s. 260.

${ }^{25}$ Wyrok WSA z dnia 4 kwietnia 2013 roku, II SA/Po 552/12, CBOSA.

${ }^{26} \mathrm{~W}$ orzecznictwie sądów administracyjnych przyjmowane jest stanowisko, zgodnie z którym tak zwana zasada swobody umów, pojmowana jako przyznanie podmiotom prawa cywilnego kompetencji do swobodnego decydowania: o zawarciu umowy, o osobie kontrahenta, o treści umowy oraz o formie umowy, doznaje pewnych ograniczeń. Gmina, powierzając wykonanie zadań własnych podmiotowi zewnętrznemu, musi postępować według określonych procedur. Nie może samodzielnie, według własnego uznania, realizować tych zadań, podobnie jak nie może ich samodzielnie kreować. Zob. wyrok NSA z dnia 3 grudnia 2014 roku, II GSK 2669/14, LEX nr 1646221. Zob. także: A. Czajka, Dualizm środków ochrony prawnej partnerstw publiczno-prywatnych jedno- 
przyznanie podmiotom prawa cywilnego kompetencji do swobodnego decydowania: o zawarciu umowy, o osobie kontrahenta, o treści umowy oraz o formie umowy, doznaje pewnych ograniczeń.

Analizując przysługującą jst swobodę decydowania w aspekcie samego faktu zawarcia umowy, należy zauważyć, że art. 9 upo nie nakłada na jst obowiązku zawarcia umowy, której przedmiotem jest przekazanie prowadzenia szkoły podmiotowi prywatnemu (osobie fizycznej lub osobie prawnej). Jednocześnie jst mają pewien margines swobody w zakresie ukształtowania treści umowy (granicą omawianej swobody są przepisy upo przewidujące wymóg wprowadzenia do treści danej umowy bezwzględnie obowiązujących jej elementów - art. 9 ust. 3 upo). Brak któregokolwiek z elementów wskazanych w przywołanym powyżej przepisie powodowałby, iż byłaby to czynność prawna sprzeczna z ustawą i, co za tym idzie, obarczona wadą powodującą jej nieważność z mocy prawa ${ }^{27}$.

Powyższy wywód skłania do wniosku, że w toku przekazywania prowadzenia szkoły publicznej przez jst podmiotowi zewnętrznemu występują czynności regulowane przepisami upo (podjęcie uchwały intencyjnej przez organ stanowiący jst i wydanie opinii przez organ sprawujący nadzór pedagogiczny), jak również klasyczna czynność cywilnoprawna, jaką jest zawarcie przez jst umowy z podmiotem zewnętrznym (na przykład organizacją pozarządową), który zamierza przejąć prowadzenie szkoły.

Warto też podnieść, że treść art. 9 ust. 1 upo wyraźnie wskazuje, iż mamy do czynienia $\mathrm{z}$ „umową przekazania prowadzenia szkoły samorządowej” określonemu podmiotowi, a nie, jakby się wydawać mogło, „umową lub umowami w zakresie prowadzenia szkół”. Jakkolwiek przekazanie prowadzenia szkoły jednoznacznie powiązane zostało przez ustawodawcę z zawarciem umowy, a więc z czynnością cywilnoprawną ${ }^{28}$, to jednak nie uniemożliwia zawierania kolejnych umów ją wspierających lub jej towarzyszących.

\section{UWAGI KOŃCOWE}

Można powiedzieć, że zarówno w przypadku umowy o przekazanie prowadzenia szkoły na gruncie upo, jak i zawieranych umów o wsparcie realizacji zadania publicznego lub o powierzenie realizacji zadania publicznego z wyłonionymi organizacjami pozarządowymi w trybie udppw ustawodawca dokonał kolejnego ruchu w kwestii prywatyzacji zadań publicznych. Dodać należy ponadto, że w obu

stek samorzqdu terytorialnego, [w:] Samorzad terytorialny a sq̨dowa kontrola administracji, red. B. Dolnicki, J.P. Tarno, Warszawa 2012, s. 59.

27 Zob. art. 58 § 1 ustawy z dnia 23 kwietnia 1964 roku Kodeks cywilny, tekst jedn. Dz.U. z 2019 r. poz. 1145, 1495. Także w tej sprawie: wyrok WSA z dnia 4 kwietnia 2013 roku, II SA/Po 552/12, CBOSA.

28 Zob. też wyrok NSA z dnia 4 kwietnia 2013 roku, I OSK 93/13, CBOSA. 
przypadkach współpraca podmiotów publicznych i niepublicznych oparta na umowie cechuje się wzmożonym korzystaniem przez administrację publiczną z tak zwanych cywilnoprawnych form aktywności.

Zarówno powierzanie realizacji zadań publicznych w trybie udppw, jak i przekazanie prowadzenia szkoły na gruncie upo stanowią formułę swoistej, funkcjonalnej prywatyzacji świadczenia usług społecznych ${ }^{29}$. Z powyższego wynika, że zadanie będące przedmiotem współpracy nie utraci charakteru publicznego, gdyż ustawowa odpowiedzialność za jego realizację nadal spoczywać będzie na podmiocie publicznym ${ }^{30}$.

W związku z poczynionymi wyżej spostrzeżeniami uprawnione wydaje się stwierdzenie, że wypracowanie jednolitego modelu zlecania realizacji zadań publicznych na gruncie upo (rozciągnięcie na tę sferę odpowiedniego stosowania w zakresie wyboru podmiotu przejmującego szkołę przepisów udppw dotyczących powierzania lub wspierania realizacji zadań publicznych organizacjom pozarządowym) nie jest wyłącznie sprawą teoretyczną, rzutuje ono bowiem na całe ustawodawstwo. Nieuporządkowanie koncepcyjne i brak jednolitych rozwiązań prowadzą do niespójności systemu prawnego.

\title{
CONTRACT ON THE TRANSFER OF SCHOOL MANAGEMENT BY A NON-GOVERNMENTAL ENTITY. A FEW REMARKS ON THE CURRENT STATE ACCORDING TO EDUCATIONAL LAW
}

\author{
Summary
}

The Educational Law Act, by using the concept of a contract and providing its necessary elements, does not aspire to treat it as a typical named contract, i.e. one whose content is normatively provided for. According to the assumptions underlying the Educational Law Act, this contract is to be understood rather as a way of implementing a public task, within a contract containing the necessary elements characteristic to a given type of civil law contract.

Keywords: state school, public tasks, privatisation of public tasks, contract governed by public law, contract governed by private law

\section{BIBLIOGRAFIA}

Biernat S., Prywatyzacja zadań publicznych (zarys problematyki), „Państwo i Prawo” 1993, z. 5. Blicharz J., Problem implementacji dyrektywy ustugowej UE w odniesieniu do organizacji trzeciego sektora w Polsce, „Przegląd Prawa i Administracji” 79, 2009.

${ }^{29}$ H. Izdebski, M. Kulesza, Administracja publiczna. Zagadnienia ogólne, Warszawa 2004, s. 1.

30 Samo zadanie, które jest przedmiotem zlecenia, zachowuje publiczny charakter, ale istnieje możliwość, by było bezpośrednio wykonywane przez podmiot niepubliczny - zob. S. Biernat, Prywatyzacja zadań publicznych (zarys problematyki), „Państwo i Prawo” 1993, z. 5, s. 6-7. 
Blicharz J., Ustawa o działalności pożytku publicznego i o wolontariacie. Ustawa o spółdzielniach socjalnych. Komentarz, Warszawa 2012.

Blicharz J., Wplyw społeczeństwa obywatelskiego na efektywność zarzadzania w administracji publicznej (wybrane problemy), [w:] Między tradycją a przyszlościa w nauce prawa administracyjnego, red. J. Supernat, Wrocław 2009.

Czajka A., Dualizm środków ochrony prawnej partnerstw publiczno-prywatnych jednostek samorzadu terytorialnego, [w:] Samorzad terytorialny a sqdowa kontrola administracji, red. B. Dolnicki, J.P. Tarno, Warszawa 2012.

Izdebski H., Kulesza M., Administracja publiczna. Zagadnienia ogólne, Warszawa 2004.

Kmieciak Z., Stahl M., Akty nadzoru nad działalnościa samorzadu terytorialnego ( $w$ świetle ustaleń orzecznictwa NSA i poglądów doktryny), „Samorząd Terytorialny” 2001, nr 1-2.

Kocowski T., Umowa w działaniach administracji publicznej, [w:] Stan i kierunki rozwoju nauk administracyjnych, red. A. Błaś, J. Boć, Wrocław 2014.

Kurzyna-Chmiel D., Oświata jako zadanie publiczne, Warszawa 2013.

Miruć A., O roli i specyfice umów w dziataniach administracji pomocy społecznej, [w:] Cywilizacja administracji publicznej. Księga jubileuszowa z okazji 80-lecia urodzin prof. nadzw. UWr dra hab. Jana Jeżewskiego, Wrocław 2019.

Pierzchała J., Prawo oświaty prywatnej, Warszawa 2016.

Pilich M., Ustawa o systemie oświaty. Komentarz, Warszawa 2012.

Rabska T., Kontrakt wojewódzki - forma działania administracji publicznej w strukturach zdecentralizowanych, [w:] Instytucje wspótczesnego prawa administracyjnego. Księga pamiątkowa prof. zw. dra hab. J. Filipka, Kraków 2001.

Raszewska-Skałecka R., Szkoła publiczna jako zdecentralizowany podmiot administracji publicznej. Studium administracyjnoprawne, Wrocław 2019.

Raszewska-Skałecka R., Trzeci sektor w systemie oświaty - wybrane formy wspierajace oświatę, [w:] Trzeci sektor i ekonomia społeczna. Uwarunkowania prawne. Kierunki rozwoju, red. J Blicharz, L. Zacharko, Wrocław 2017.

Raszewska-Skałecka R., Udziat organizacji pozarządowych w rozwiązywaniu lokalnych konfliktów edukacyjnych na tle rozwiąań prawnych, [w:] Płaszczyzny konfliktów w administracji publicznej, red. M. Tabernacka, R. Raszewska-Skałecka, Warszawa 2010.

Raszewska-Skałecka R., Współczesne wyzwania $i$ dylematy zarządzania oświata samorządową. Społeczne inicjatywy edukacyjne, [w:] Przeglad dyscyplin badawczych pokrewnych nauce prawa i postępowania administracyjnego, red. S. Wrzosek et al., Lublin 2010.

Stasikowski R., Funkcja regulacyjna administracji publicznej. Studium z zakresu nauki prawa administracyjnego oraz nauki administracji, Bydgoszcz-Katowice 2008.

Sześciło D., Prywatyzacja prowadzenia szkót samorząowych do poprawki, https://www.prawo. pl/samorzad/prywatyzacja-prowadzenia-szkol-samorzadowych-do-poprawki,98190.html (dostęp: 31.01.2020).

Trela A., Powierzanie zadań z zakresu gospodarki komunalnej a swoboda zawierania umów, „Ruch Prawniczy, Ekonomiczny i Socjologiczny" 77, 2015, z. 3.

Zacharko L., Zacharko A., Umowa publicznoprawna jako forma realizacji zadań publicznych w Unii Europejskiej, [w:] Wzajemne oddziaływanie gałęzi prawa publicznego i prywatnego, red. P. Bieś-Srokosz, J. Srokosz, E. Żelasko-Makowska, Częstochowa 2017. 